\title{
Seasonal changes in the phylloplane of genus Gnetum (Gnetaceae) representatives in greenhouse conditions
}

\section{Ianina Bogdanova (Pagoda) ${ }^{1}$, Anatoly Pautov², Marina Zelenskaya², Elena Krylova ${ }^{2}$, and Dmitry Vlasov ${ }^{2,3}$}

${ }^{1}$ Laboratory of Paleobotany, Komarov Botanical Institute, Russian Academy of Sciences, Professora Popova Str., 2, Saint Petersburg, 197376, Russian Federation

${ }^{2}$ Department of Botany, Faculty of Biology, Saint Petersburg State University, Universitetskaya nab., 7-9, Saint Petersburg, 199034, Russian Federation

${ }^{3}$ Laboratory of Fungal Biochemistry, Komarov Botanical Institute, Russian Academy of Sciences, Professora Popova Str., 2, Saint Petersburg, 197376, Russian Federation

Address correspondence and requests for materials to lanina Bogdanova (Pagoda), ianinapagoda@gmail.com

Citation: Bogdanova, I., Pautov, A., Zelenskaya, M., Krylova, E., and Vlasov, D. 2019. Seasonal changes in the phylloplane of genus Gnetum (Gnetaceae) representatives in greenhouse conditions. Bio. Comm. 64(4): 260-269. https://doi. org/10.21638/spbu03.2019.405

Author's information: Ianina Bogdanova (Pagoda), Master of Sci. in Biology, PhD student, orcid.org/0000-0002-0378-0773. Anatoly Pautov, Dr. of Sci. in Biology, Professor, Head of Department, orcid. org/0000-0001-7603-4539; Marina Zelenskaya, PhD, Senior Researcher, orcid. org/0000-0003-3588-8583; Elena Krylova, Junior Researcher, orcid.org/0000-00030686-0661; Dmitry Vlasov, Dr. of Sci. in Biology, Professor, Leading Researcher, orcid.org/0000-0002-0455-1462

Manuscript Editor: Anton Nizhnikov, Department of Genetics and Biotechnology, Faculty of Biology, Saint Petersburg State University, Saint Petersburg, Russia

Received: October 14, 2019;

Revised: November 25, 2019

Accepted: November 28, 2019;

Copyright: ๑ 2019 Bogdanova et al. This is an open-access article distributed under the terms of the License Agreement with Saint Petersburg State University, which permits to the authors unrestricted distribution, and self-archiving free of charge.

Funding: The reported study was funded by RFBR according to Research Project № 18-34-00912. The work was partially carried out on the theme AAAA-A19-119020890079-6 "Biodiversity, ecology and structural and functional features of fungi and mushroom-like protists".

Competing interests: The authors have declared that no competing interests exist.

\section{Abstract}

The leaf surface, or phylloplane, is inhabited by various microorganisms. Micromycetes are typical organisms of the phylloplane that are able to exert negative effects on plants. Seventeen species of micromycetes were indicated in the phylloplanes of G. gnemon and G. montanum. Micromycetes form biofilms on the surface of the upper epidermis. In the lower epidermis, they mainly colonize cork warts and destroy their cells. Collapsing cells and the micromycetes are isolated from the living tissues of leaves by layers of densely arranged cells. During changes from season to season, the number of disappearing micromycete species in the upper epidermis is approximately equal to the number of appearing new species. The total number of micromycete species in the phylloplane of the lower epidermis is reduced in winter. Structural organization, biodiversity, seasonal changes in the phylloplane and the influence of its micromycetes on leaf cells differ in the upper and lower epidermis of Gnetum leaves.

Keywords: phylloplane, micromycetes, Gnetum, epidermis, cork warts.

\section{Introduction}

Various microorganisms, among which microscopic fungi play a special role, usually inhabit the surface of plant leaves (Levetin and Dorsey, 2006). Yeast and filamentous fungi are considered the main inhabitants of the phylloplane (Irga, Burchett, O'Reilly, and Torpy, 2006). Together with other microorganisms, they form peculiar communities on the leaves. Among the most common inhabitants of the leaves of various plants, most prevalent are Alternaria alternata, Cladosporium cladosporioides, Gliocladum viridae, Mucor racemosus and Penicillium chrysogenum; these species are found around the world (Ajay, Aparajita, and Das, 2013). There are fungi of the phylloplane that grow in certain terrestrial ecosystems. For example, Cladosporium oxysporum is a common species for plants in tropical ecosystems (Ellis, 1971; Lee and Hyde, 2002). Another species, Cladosporium cladosporioides, is a characteristic component for the phylloplane of temperate climates (Ajay, Aparajita, and Das, 2013). The typical fungi of a mangroid phylloplane are Cladosporium cladosporioides, C. oxysporum, Penicillium sp., Phoma sp., Pestalotiopsis oxyanthi, P. maculans, Arthrinium sp., Colletotrichum sp. and Trimmatostroma sp. (Kuthubutheen, 1984). The study of phylloplane mycobiota has also been carried out in greenhouses, although only a few works have been devoted to this. Among them, there is the study of mycobiotic plants of the botanical garden in Pavia (Northern Italy), which focused on the biodiversity of micromycetes of 
the phylloplanes and in air in the greenhouses (Rodolfi, Legler, and Rinaldi, 2006). The authors showed that the greatest concentration of fungi spores in the air occurs in the tropical and Mediterranean greenhouse. In total, 72 species of micromycetes belonging to 42 genera were isolated from the air and from leaf surfaces. Many fungi species found in the air were extracted from leaf surfaces. Potential pathogens for humans were found among them. The authors noted the importance of monitoring mycobiota in greenhouses of botanical gardens (Rodolfi, Legler, and Rinaldi, 2006). Non-pathogenic phylloplane fungi use as food sources excretions from plants, as well as substances deposited from the atmosphere (Inacio et al., 2002; Gonsalez and Tello, 2010).

Spores of fungi usually reach the surface of the leaf accidentally by means of wind or rain. Their attachment and subsequent germination depend on the properties of the spores themselves, environmental factors, and the features of the leaf surfaces (Andrews, Spear, and Nordheim, 2002). High humidity promotes successful germination of fungal spores and the growth of the mycelium (Collado, Platas and Gonzaloz Pelaez, 1999; Prabakaran, Merinal and Panneerselvam, 2011).

The diversity of phylloplane micromycetes varies during the year (Borogohain et al., 2014). This can be explained by external conditions, the ecological characteristics of the fungi, their competitive ability, life cycles, and various potential for utilization of organic substances that are deposited from the atmosphere or excreted by the plant (Blakeman, 1993; Bakkar et al., 2002; Ajay, Aparajita, and Das, 2013). For example, in Psidium guineense, the peak of biodiversity occurs in May, but the most notable development of Penicillium chrysogenum was observed in January (Levetin and Dorsey, 2006). In Eucalyptus viminalis, the maximum diversity of fungi occurs in the autumn-winter period, while minimum diversity is observed in summer (Inacio et al., 2002). In mangroves Kandelia candel and Aegiceras corniculatum, the greatest variety of fungi was observed in summer, and the smallest variety in winter (Lee and Hyde, 2002). There are also species of fungi with a constant presence and high distribution throughout the year. For example, Alternaria alternata is the most common micromycete that occurs throughout the year on Jartropa curcas (Borogohain, Das and Chutia, 2014).

Despite numerous studies, at present there are no comparative data on the composition, structural organization and seasonal dynamics of the upper and lower epidermis of the leaf blade phylloplanes. The objectives of this work were to study the peculiarities of micromycete colonization of the upper and lower epidermis of Gnetum (Gnetaceae) leaves, to characterize seasonal changes in the phylloplane, and to assess the influence of micromycetes on leaf tissues. The main tasks of the work included identification of specific features of distribu- tion of micromycetes on the upper and lower side of the Gnetum gnemon L. and G. montanum Markgraf (Gnetaceae) leaf blade, identification of their species diversity in different seasons, and revealing of structural changes in leaf tissues under the influence of micromycetes.

\section{Materials and Methods}

Plant material. Leaves of Gnetum gnemon and G.montanum were studied. G. gnemon is a low tree growing in tropical rain forests of southeastern Asia; G. montanum is a tree liana (Won and Renner, 2006). Plant material was collected in the greenhouse of the Botanical Garden of the Komarov Botanical Institute (St. Petersburg, Russia). The research project began in September 2015 and will conclude in April 2020. In summer, the air temperature in the greenhouse often rises above $30^{\circ} \mathrm{C}$ during the day. Temperatures of $40^{\circ} \mathrm{C}$ have been recorded. During this period, plant crowns were watered daily and on particularly hot days were watered twice a day. In winter, the air temperature is $20-22^{\circ} \mathrm{C}$. Plants were watered irregularly.

\section{Mycological examination}

Fungal sampling from the phylloplane. Leaves for mycological examination were collected in May and November 2015, and in January 2016. Each time, four fully-grown leaves were sampled both from G.gnemon and from G. montanum. The leaves of G. gnemon were taken from the middle part of the crown periphery. The leaves of G.montanum were chosen from the upper, middle and lower parts of the stalk of the liana. The collected material was used for isolation of phylloplane micromycetes in a pure culture and for the study of the phylloplane using light and electron scanning microscopy.

Mycological objects were selected in four ways. The first of them was point isolation via transfer of fungal structures (mycelium and conidia) with a preparation needle to the nutrient medium in Petri dishes. This method was used for the isolation of micromycetes from the abaxial side of the leaf. Samples were taken along the main vein and secondary veins, as well as from cork warts. Secondly, samples from the upper surface of the leaves were taken on sterile swabs at sites with a dark plaque, where the development of dark-colored mycelium and its sporulation indicated the presence of micromycetes (Fig. 1). Thirdly, fungal fragments were collected by imprinting from the leaf surface of G. gnemon and G. montanum on the nutrient medium of imprinting replicas. Finally, plating was carried out via flushing from the surface of the leaf.

Fungal sampling from the air. In addition, the presence of micromycetes in the greenhouse air was evaluated. The diversity of the aeromycota was analyzed using 


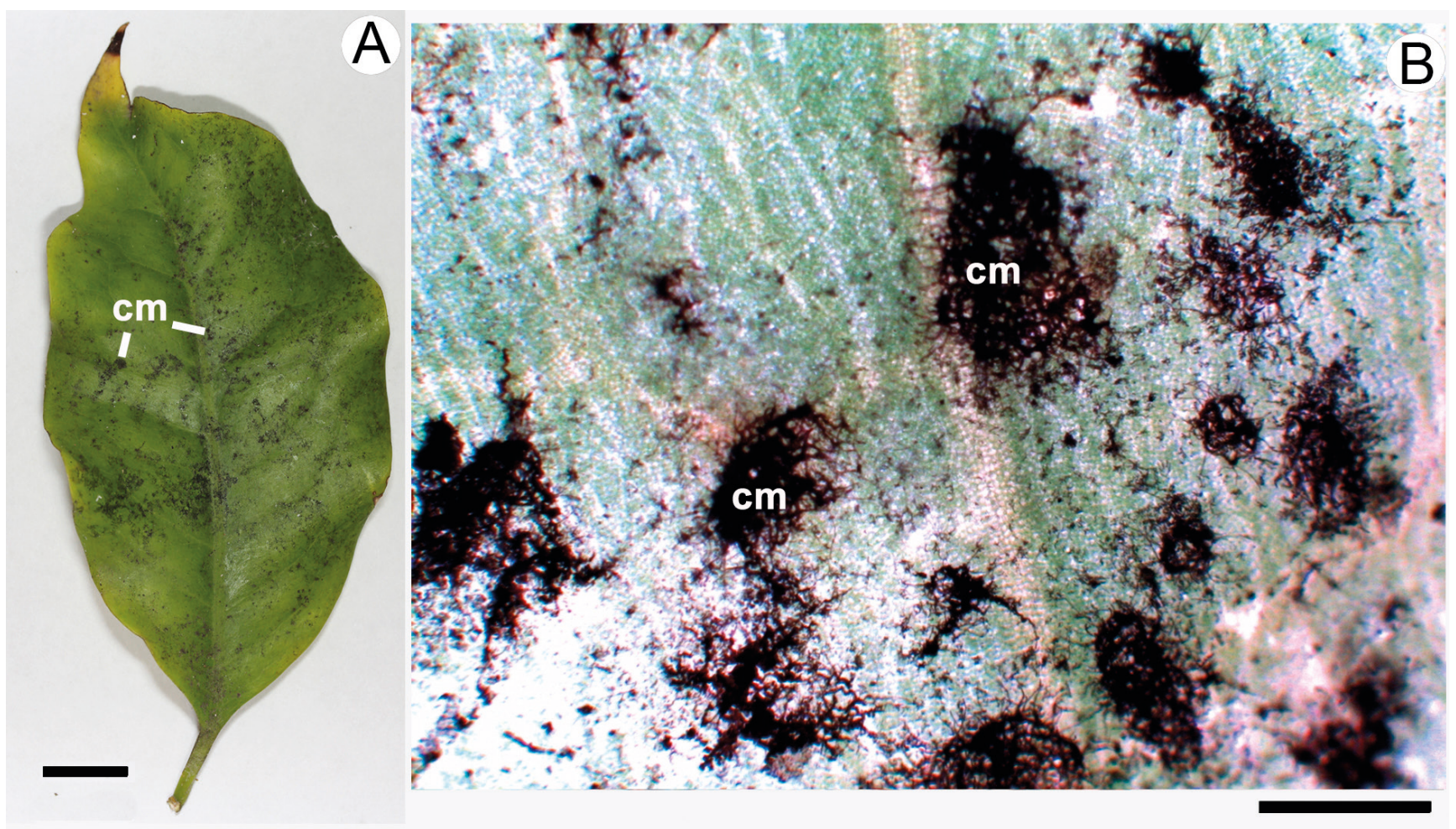

Fig. 1. Colonies of micromycetes on the leaf surface of G. gnemon. A - mature leaf with black fungal film-like deposit. B - fragment of leaf surface with dark-colored mycelia colonies (cm). A $-10 \mathrm{~mm}$; B $-500 \mu \mathrm{m}$.

the sedimentation method. Open Petri dishes with Czapek Dox Agar medium were exposed to the air for $1 \mathrm{hr}$ in June 2016. The cups were placed in close proximity to the studied plants at soil level and at heights of $1 \mathrm{~m}$ and $2.5 \mathrm{~m}$.

Identification of fungal species. Identification was carried out after germination and formation of colonies. The fungal species were identified based on cultural characteristics and morphology of fruiting bodies and spores by using standard texts and keys within the identification manuals (Ellis, 1971, 1976; Hoog and Hermanides-Nijhof, 1977; Hoog and Guarro, 1995; Satton, Fotergill and Rinaldi, 2001). Verification of species in accordance with modern nomenclature was carried out using the electronic database Index Fungorum (http:// www.indexfungorum.org/NAMES/NAMES.asp).

Comparison of the lists of fungal species. The occurrence frequency (\%) of fungi species was estimated via the number of leaves where this species was detected.

In order to assess the seasonal changes in the species composition of G.gnemon and G. montanum phylloplane mycobiota, the lists of micromycetes species that were found on their leaves in different seasons were compared. To compare the lists, the Jaccard coefficient (Schmidt, 1984) was used:

$$
K_{j}=\frac{C}{A+B-C},
$$

where $A$ is the number of micromycetes species in the G. gnemon phylloplane, $B-$ the number of micromycete species in the G. montanum phylloplane, $C-$ the number of micromycete species which are present in both the G. gnemon and G. montanum phylloplanes. The Jaccard coefficient can take values $K_{j}$ from 0 to $1 . K_{j}=1$ means complete similarity of the mycobiota in G.gnemon and G. montanum phylloplanes (absolute coincidence of the lists of micromycetes that are present in the phylloplanes of G. gnemon and G. montanum). $K_{j}=0$ means that the phylloplanes of G.gnemon and G.montanum do not have a single common species of micromycete.

Light and scanning electron microscopy. Distribution of micromycetes on the surface and within the tissues of the leaves was studied via methods of light and scanning electron microscopy. To make cross-section slides of leaves, their fragments were dehydrated through a series of alcohols of increasing concentrations, poured into paraffin, and then transferred to a hydrophobic medium ( $\beta$-limonene) (Barykina et al., 2000). Slides were made on a microtome SAKURA Accu-Cut SRM 200 (Japan). After the cutting, samples were rehydrated. The material was stained with the combined dye alcyan blue 
Table 1. Frequency indexes (\%) of phylloplane fungi in leaves of G. gnemon

\begin{tabular}{|c|c|c|c|c|c|c|}
\hline \multirow{3}{*}{ Species of fungi } & \multirow{2}{*}{\multicolumn{2}{|c|}{$\begin{array}{c}\text { May } \\
\text { epidermis }\end{array}$}} & \multirow{2}{*}{\multicolumn{2}{|c|}{$\begin{array}{l}\text { November } \\
\text { epidermis }\end{array}$}} & \multirow{2}{*}{\multicolumn{2}{|c|}{$\begin{array}{c}\text { January } \\
\text { epidermis }\end{array}$}} \\
\hline & & & & & & \\
\hline & abaxial & adaxial & abaxial & adaxial & abaxial & adaxial \\
\hline Alternaria alternata (Fr.) Keissl. & 0 & 0 & 100 & 50 & 100 & 100 \\
\hline Cladosporium cladosporioides (Fresen.) G. A. de Vries & 100 & 100 & 100 & 100 & 100 & 100 \\
\hline C. sphaerospermum Penz. & 50 & 25 & 0 & 25 & 100 & 0 \\
\hline Penicillium brevicompactum Dierckx & 25 & 25 & 0 & 50 & 0 & 0 \\
\hline P. citrinum Thom & 0 & 0 & 100 & 0 & 0 & 50 \\
\hline P. decumbens Thom & 0 & 0 & 100 & 50 & 0 & 50 \\
\hline P. herqueri Bainier \& Sartory & 50 & 0 & 0 & 0 & 0 & 50 \\
\hline Penicillium sp. & 0 & 25 & 0 & 0 & 0 & 0 \\
\hline Phoma herbarum Westend. & 100 & 75 & 0 & 50 & 0 & 0 \\
\hline Rhizopus stolonifer (Ehrenb.) Vuill. & 0 & 25 & 0 & 0 & 0 & 0 \\
\hline Sarocladium strictum (W. Gams) Summerb. & 0 & 0 & 0 & 0 & 0 & 50 \\
\hline Sclerotinia sclerotiorum (Lib.) de Bary & 0 & 0 & 0 & 0 & 0 & 50 \\
\hline mycelia sterilia, light-colored & 50 & 100 & 0 & 25 & 0 & 50 \\
\hline mycelia sterilia, dark-colored & 0 & 25 & 0 & 0 & 0 & 0 \\
\hline
\end{tabular}

and safranin. All specimens were poured into a glycerin-gelatin mixture. Viewing and photographing of the slides were carried out using a Leica EZ4 binoculars, Leica DM500 microscopes, Leica DM1000 microscope and Leica EC3 digital camera (Germany).

The staining of cork warts on suberin was produced by potassium hydroxide $(\mathrm{KOH})$ which stained them a bright yellow color (Barykina et al., 2000). The fragments of blade and petiole epidermis with cork warts and its transverse sections were heated in a $30 \%$ solution of potassium chloride.

For scanning electron microscopy the leaf fragments were dehydrated in a series of ethanol of increasing concentrations $(20 \%, 50 \%, 70 \%, 80 \%, 90 \%, 96 \%$, $100 \%)$. Then, they were dipped into mixtures of acetone and ethanol (100\%), acetone and isoamyl acetate and isoamyl acetate only. Dehydrated specimens underwent critical point drying using liquid carbon dioxide $\left(\mathrm{CO}_{2}\right)$. Dried objects were applied to specimen holders and sprayed with ions of gold. We used a scanning electron microscope JSM-6390LA (Japan) for examination of prepared specimens.

\section{Results}

Micromycetes of the phylloplane in G.gnemon. We identified 14 species of micromycetes in the G.gnemon phylloplane (Table 1). Cladosporium cladosporioides was found in all of the samples taken from the leaf surface. The occurrence of other micromycetes varies throughout the year. Some of them were found only during one season.

The total number of fungi species in the phylloplane of the upper epidermis counts 7-8 species throughout the year. In transition from season to season, the number of micromycetes that disappear from the upper epidermis is approximately equal to the number of species emerging. For example, in the May phylloplane of G. gnemon in comparison with the January phylloplane, 5 species of micromycetes disappear and 6 new ones colonize (Table 1). In the November phylloplane in comparison with the May phylloplane, 4 species disappear and 2 new ones settle. In the January phylloplane in comparison with the November phylloplane, 4 species disappear and 4 new ones colonize.

The total number of fungi species in the lower epidermis is reduced from 6 in the spring season to 4 in autumn and 3 in winter. Species detected in the winter phylloplane are widely distributed and are found in all of the specimens.

Micromycetes of the phylloplane in G.montanum. We isolated 14 species of micromycetes from the phylloplane of G. montanum (Table 2). C.cladosporioides was discovered in all of the samples. Some species of micromycetes were found during only one of the seasons. 
Table 2. Frequency indexes (\%) of phylloplane fungi in leaves of G. montanum

\begin{tabular}{|c|c|c|c|c|c|c|}
\hline \multirow{3}{*}{ Species of fungi } & \multirow{2}{*}{\multicolumn{2}{|c|}{$\begin{array}{c}\text { May } \\
\text { epidermis }\end{array}$}} & \multirow{2}{*}{\multicolumn{2}{|c|}{$\begin{array}{l}\text { November } \\
\text { epidermis }\end{array}$}} & \multirow{2}{*}{\multicolumn{2}{|c|}{$\begin{array}{c}\text { January } \\
\text { epidermis }\end{array}$}} \\
\hline & & & & & & \\
\hline & abaxial & adaxial & abaxial & adaxial & abaxial & adaxial \\
\hline Acremonium sp. & 25 & 0 & 0 & 0 & 0 & 0 \\
\hline Alternaria alternata & 0 & 0 & 0 & 25 & 0 & 100 \\
\hline Cladosporium cladosporioides & 100 & 100 & 100 & 100 & 100 & 100 \\
\hline $\begin{array}{l}\text { Paecilomyces divaricatus (Thom) Samson, Houbraken \& } \\
\text { Frisvad }\end{array}$ & 0 & 0 & 0 & 0 & 0 & 50 \\
\hline Penicillium brevicompactum & 25 & 50 & 0 & 25 & 0 & 0 \\
\hline P. citrinum & 0 & 0 & 0 & 0 & 0 & 50 \\
\hline P. decumbens & 25 & 0 & 100 & 25 & 100 & 50 \\
\hline P. herqueri & 0 & 50 & 0 & 0 & 0 & 100 \\
\hline Phoma herbarum & 50 & 100 & 50 & 25 & 0 & 0 \\
\hline Rhizopus stolonifer & 75 & 0 & 0 & 0 & 0 & 0 \\
\hline Sclerotinia sclerotiorum & 0 & 0 & 0 & 0 & 0 & 50 \\
\hline $\begin{array}{l}\text { Talaromyces purpureogenus Samson, Yilmaz, Houbraken, } \\
\text { Spierenb., Seifert, Peterson, Varga \& Frisvad }\end{array}$ & 0 & 0 & 50 & 0 & 0 & 0 \\
\hline mycelia sterilia, light-colored & 25 & 100 & 0 & 0 & 0 & 0 \\
\hline mycelia sterilia, dark-colored & 25 & 50 & 0 & 0 & 0 & 0 \\
\hline
\end{tabular}

Table 3. Jaccard coefficient of similarity between the lists of micromycetes species estimated for the leaves of G. gnemon and G. montanum in different seasons throughout the year

Correlation coefficients are presented as only the digits following the decimal point. The values of $\mathrm{K}_{\mathrm{j}}>0.55$ are marked by italics and boldface. $M_{G \text {. g. }} N_{G \text {. g. }} J_{G . g .}$ - Jaccard coefficient for phylloplane mycobiota of G. gnemon in May, November and January phylloplanes; $\mathrm{M}_{\mathrm{G} . \mathrm{m} .}$ $\mathrm{N}_{\mathrm{G} . \mathrm{m} .,} \mathrm{J}_{\mathrm{G} . \mathrm{m} .}$ - Jaccard coefficient for phylloplane mycobiota of G. montanum in May, November and January.

\begin{tabular}{|c|c|c|c|c|c|}
\hline & $\mathbf{M}_{\text {G.g. }}$ & $\mathbf{N}_{\text {G.g. }}$ & JG.g. & $\mathbf{M}_{\mathrm{G} . \mathrm{m} .}$ & $\mathbf{N}_{\text {G. }}$. \\
\hline $\mathbf{M}_{\mathrm{G.g}}$ & - & & & & \\
\hline $\mathbf{N}_{\text {G. g. }}$ & 417 & - & & & \\
\hline JG.g. & 286 & 545 & - & & \\
\hline$M_{G . m .}$ & 636 & 417 & 286 & - & \\
\hline $\mathbf{N}_{\text {G. }}$. & 250 & 555 & 250 & 363 & - \\
\hline JG. m. & 143 & 363 & 600 & 231 & 300 \\
\hline
\end{tabular}

The total number of micromycetes in the phylloplane of the upper epidermis counts 5-7 species throughout the year. In comparison with the winter phylloplane in the spring phylloplane, 5 species of micromycetes disappear and 4 others appear. In the winter phylloplane compared with the autumn one, 2 species disappear and 3 new ones appear (Table 2).

The total number of species in the lower epidermis is reduced from 8 in the May phylloplane to 4 in the No- vember phylloplane and 2 in the January phylloplane. Species detected in the winter phylloplane were found in all of the samples taken from the leaf surface.

Comparison of the lists of fungal species. The Jaccard coefficient was calculated to compare the lists of micromycete species that were found on the leaves of the studied plants in different seasons throughout the year (Table 3). The highest values of this coefficient, and hence the highest similarity, were found between spring and autumn mycobiota. This similarity is higher than that found between spring, autumn, and winter mycobiota in both G.gnemon and G. montanum.

Micromycetes in the greenhouse air. We found 20 species of micromycetes in the greenhouse air (Table 4). Of these, 15 were found at the soil level and 14 species each at heights of $1 \mathrm{~m}$ and $2.5 \mathrm{~m}$. A total of 10 species of micromycetes were found at all these heights. C. cladosporioides and light-colored mycelia sterilia are dominating. They were found in all of the samples.

The 10 species of micromycetes found in the air were also indicated in the phylloplanes (Table 4). At the same time, 10 species of microscopic fungi that were absent from the leaf surface were found in the air samples. On the contrary, 7 species of micromycetes were present in the phylloplane, but they were not found in the air. 
Table 4. List of microscopic fungi species in air and on the phylloplanes of G. gnemon and G. montanum

\begin{tabular}{|c|c|c|c|}
\hline \multirow{2}{*}{ Species of micromycetes } & \multirow{2}{*}{ Air } & \multicolumn{2}{|c|}{ Phylloplane } \\
\hline & & G. gnemon & G. montanum \\
\hline Acremonium sp. & + & & + \\
\hline Alternaria alternata & & + & + \\
\hline Aspergillus niger Tiegh. & + & & \\
\hline A. ochraceus G. Wilh. & + & & \\
\hline A. versicolor (Vuill.) Tirab. & + & & \\
\hline Botrytis cinerea Pers. & + & & \\
\hline $\begin{array}{l}\text { Cladosporium } \\
\text { cladosporioides }\end{array}$ & + & + & + \\
\hline C. herbarum (Pers.) Link & + & & \\
\hline C. sphaerospermum & + & + & \\
\hline Paecilomyces divaricatus & & & + \\
\hline Penicillium brevicompactum & + & + & + \\
\hline P. citrinum & + & + & + \\
\hline P. commune Thom & + & & \\
\hline P. decumbens & + & + & + \\
\hline P. expansum Link & + & & \\
\hline P. griseofulvum Dierckx & + & & \\
\hline P. herquei & & + & + \\
\hline Penicillium sp. & & + & \\
\hline Phoma herbarum & & + & + \\
\hline Phoma sp. & + & & \\
\hline Rhizopus stolonifer & + & + & + \\
\hline Sarocladium strictum & & + & \\
\hline Sclerotinia sclerotiorum & & + & + \\
\hline $\begin{array}{l}\text { Stachybotrys chartarum } \\
\text { (Ehrenb.) S. Hughes }\end{array}$ & + & & \\
\hline Talaromyces purpureogenus & + & & + \\
\hline mycelia sterilia, dark-colored & + & + & + \\
\hline mycelia sterilia, light-colored & + & + & + \\
\hline
\end{tabular}

Colonization of the upper and lower epidermis of the leaf blade by micromycetes. Biofilms composed of the mycelia and generative structures of micromycetes were formed on the upper side of both G.gnemon and G. montanum leaves (Fig. 2).

Intensive development of micromycetes on the lower side of the leaves were confined mainly to the cork warts. Cork warts develop in local leaf areas because of periclinal divisions of the epidermal and subepidermal

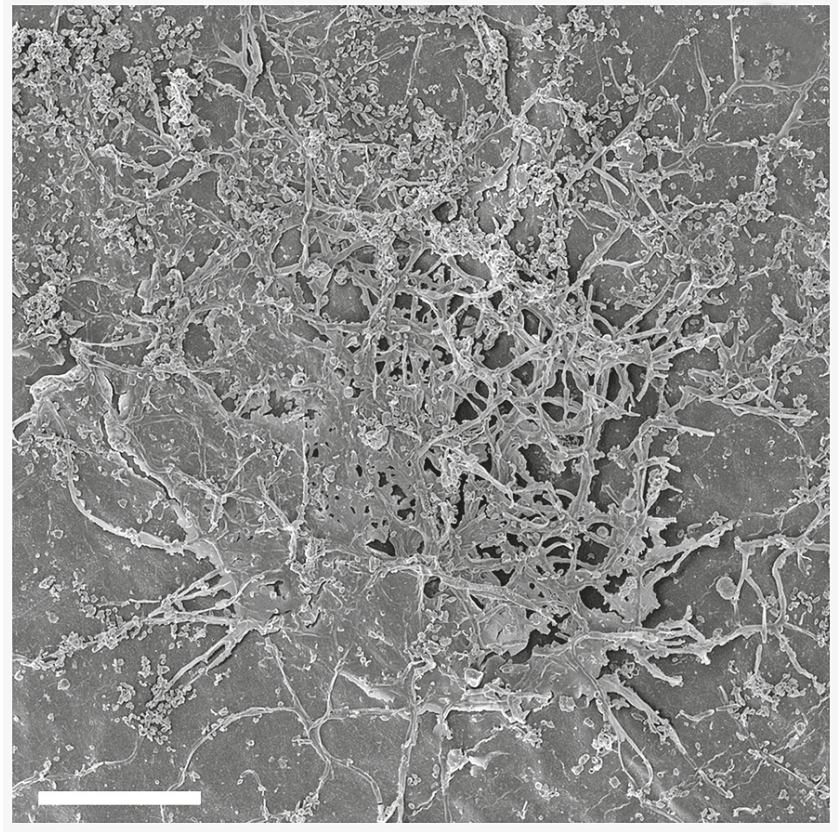

Fig. 2. Colonies of micromycetes forming biofilm on the leaf surface of G. gnemon. $100 \mu \mathrm{m}$.

cell layers (Fig. 3a, b). Besides, the development of cork warts could be accompanied by hypertrophied growth of leaf cells (Fig. 3c). The resulting cells put pressure on the cuticle. This leads to a protrusion of the cuticle above the leaf surface and the development of cracks in it (Fig. 3d). Micromycetes penetrate inside the warts through these breaks. Fungal hyphae and their spores were found regularly in the intercellular spaces and cavities of collapsing cells that fill the subcuticular space of the formed cork warts (Fig. 4a, b, c). Collapsing cells and micromycetes colonizing them were separated from the living tissues of the leaf by the layers of densely arranged cells that underlie the cork wart (Fig. 4d). The walls of these cells contain suberin.

\section{Discussion}

This research revealed 17 species of micromycetes in the phylloplane of G.gnemon and G. montanum leaves. These species colonize both the upper and lower surface of the blade.

It is thought that spores of micromycetes fall on the leaf surface mainly from the air. It has been repeatedly shown that the dissemination and spreading of fungal spores is promoted by rain and wind (Lee and Hyde, 2002; Levetin, 2002; Levetin and Dorsey, 2006). The results of the study are consistent with these ideas. Of the 17 micromycete species of the Gnetum phylloplane, 10 were also found in air samples. Similar factors take place in the greenhouse. When the greenhouse is ventilated, strong air currents arise. Crowns of plants are 

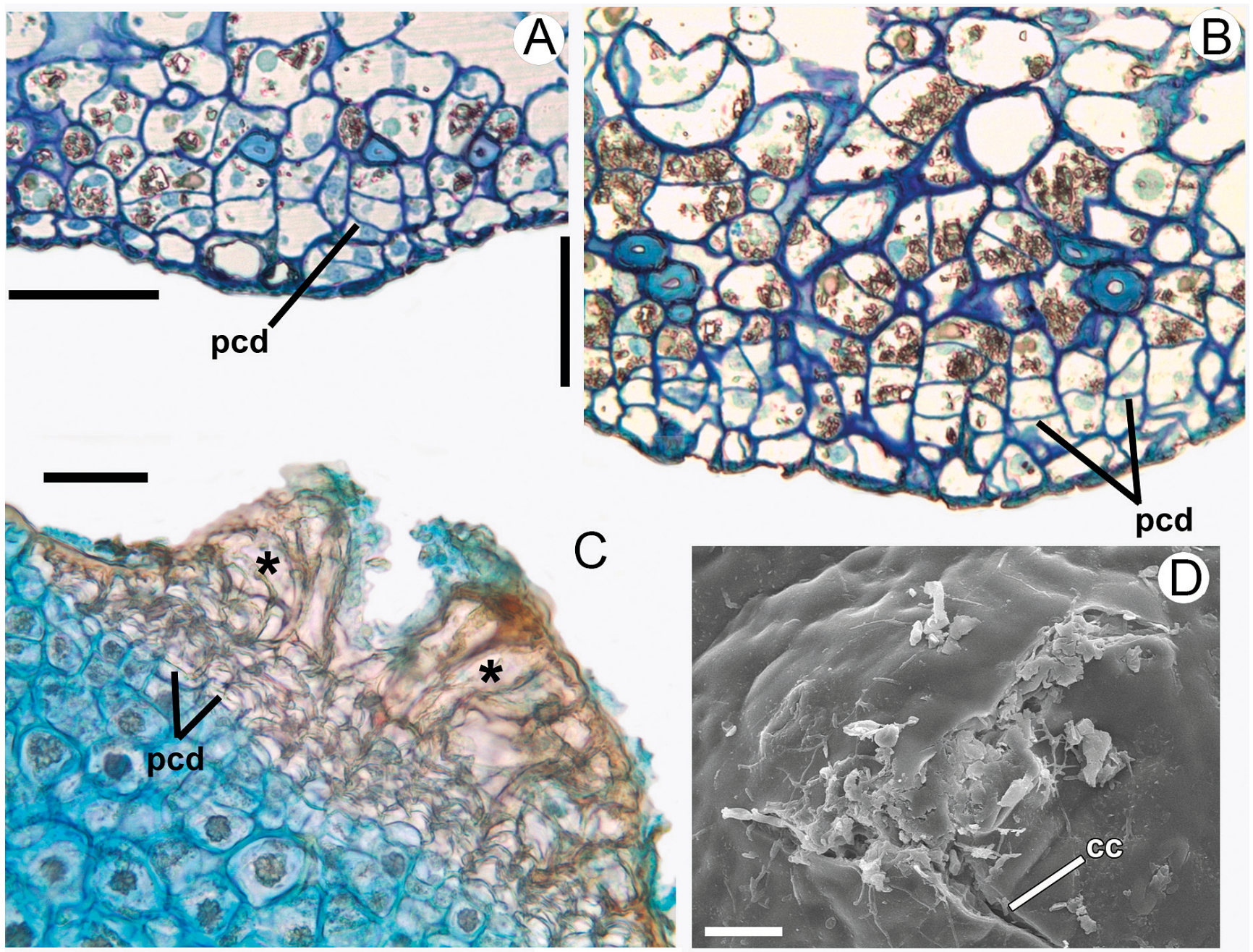

Fig. 3. Development of cork warts in G. gnemon (A, B, D) and G. montanum (C). A, B, C - transverse sections of developing cork warts. Black arrows indicate damages in the cuticle, under which the periclinal cell divisions occur. Asterisks $\left({ }^{*}\right)$ indicate hypertrophic overgrown cells of the cork wart. D - the surface of mature cork wart. pcd - periclinal cell divisions; cc - cracks in the cuticle. A, B, C - $50 \mu \mathrm{m} ; \mathrm{D}-20 \mu \mathrm{m}$.

watered by hose. The absence of some species of phylloplane micromycetes in the air samples could be the result of their sporulation during the other seasons of the year. Our data are based on the analysis of only July air samples. In addition, some micromycetes of the phylloplane are thought to be able to have a negative impact on pathogenic microorganisms (Prabakaran, Merinal and Panneerselvam, 2011; Thakur and Harsh, 2014). Our data correspond well with the previously obtained results of M. Rodolfi, S. E. Legler and A. M. Picco (2006), according to which regular exchange of micromycetes takes place between the phylloplane and the air. It is possible that the absence of some micromycetes from the air on the surface of the Gnetum leaves can be explained by interspecific influence of other micromycetes.

The attachment of spores to the leaf surface depends not only on the abilities of the spores themselves, but also on the characteristics of the leaf surface (Andrews, Spear and Nordheim, 2002). The presence of various relief irregularities on the surfaces facilitates the attachment of spores and their subsequent germination. This investigation has shown that colonization of the upper and lower epidermis of Gnetum leaves by micromycetes occurs in different ways. On the surface of the upper epidermis, they form biofilms (Fig. 2). In the lower epidermis, micromycetes mainly colonize cork warts (Fig. 4).

According to numerous data, cork warts can occur in response to both mechanical damage of the epidermis, and an excess water flow into the plant combined with obstructed transpiration (Farooqui, 1982; Guimarães, Andreata and Costa, 2011; Vaz, Souza, Alves and Arruda, 2018). Micromycetes penetrate into cork warts of Gnetum through cuticle damages (Fig. 3a, b). At the same time, mass death and destruction of cork wart cells after colonization with phylloplane micromycetes was observed. There is every reason to believe that these destructive processes are caused by micromycetes. It is known that they can have a negative effect on 


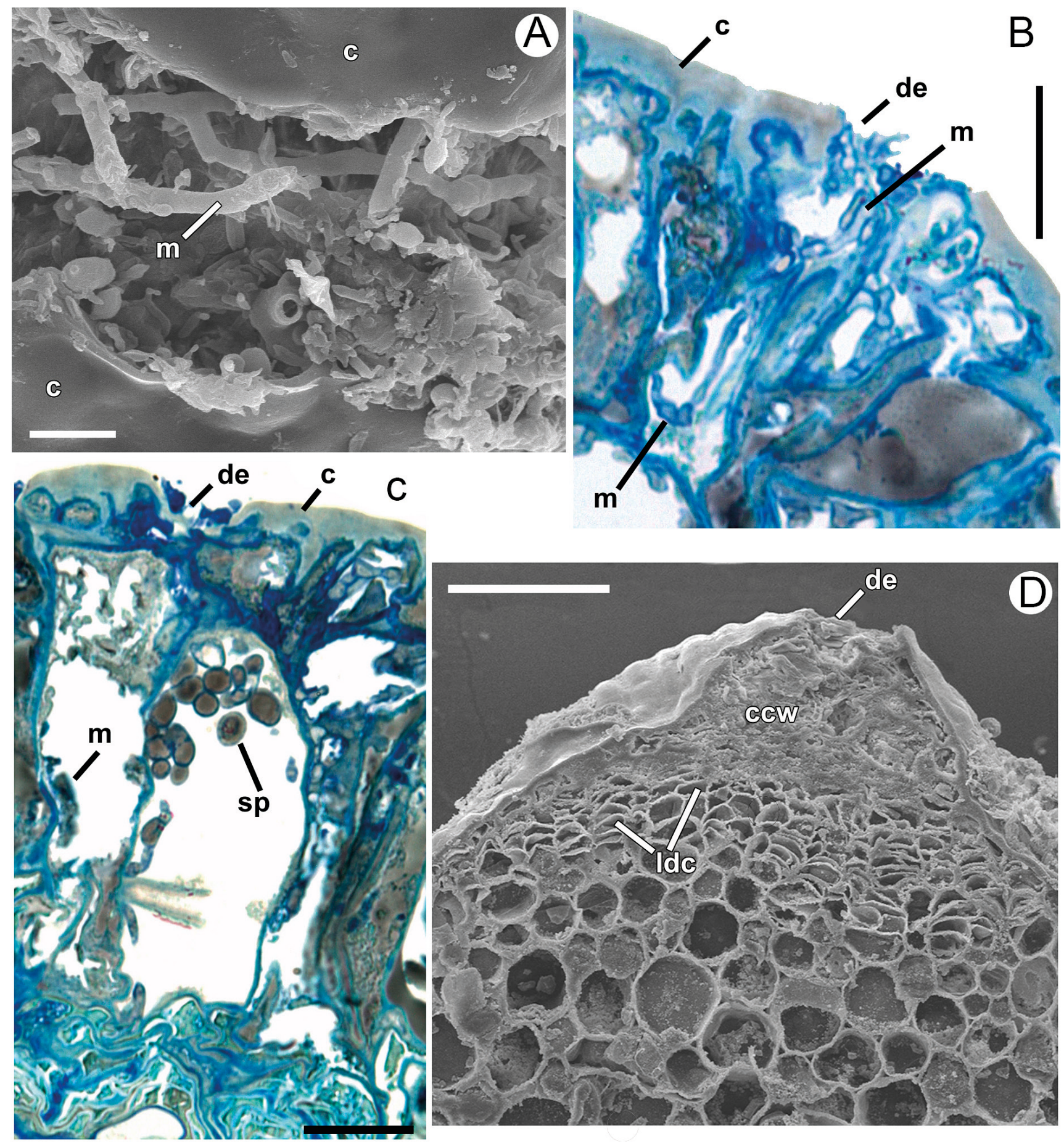

Fig. 4. Micromycetes in the phylloplane of the lower epidermis in G. gnemon leaf, A - fragment of the cork wart surface. Fungal hyphae in cracks of the wart are visible. B, C - fragments of transverse sections of the cork wart containing dead leaf cells, hyphae and spores of micromycetes. D - transverse section of mature cork wart. Layers of densely lying cells isolate living subepidermal tissues of the leaf from dead cells of the wart. c - cuticle; m - mycelia; de - destroyed epidermis; sp - spores; ldc - layers of densely lying cells; ccw - contents of the cork wart. A $-10 \mu \mathrm{m} ; \mathrm{B}, \mathrm{C}-20 \mu \mathrm{m} ; \mathrm{D}-100 \mu \mathrm{m}$.

plant cells. For example, the Gnetum phylloplane contains micromycetes that are known as biodestructors of such major cell wall components as cellulose (Cladosporium cladosporioides, C.sphaerospermum, Alternaria alternata, Phoma herbarum, Acremonium strictum) (El-Said, 2001) and pectin (C.cladosporioides, Penicil- lium brevicompactum, A. alternata, Ph. herbarum) (Luguskas, Mikulskeke and Shlyaungene, 1987). Fungi of the genus Penicillium, identified on the surface of leaves in a significant amount, are able to change the $\mathrm{pH}$ of the environment due to the release of organic acid (Barinova, Vlasov and Shchiparev, 2010). Acid production 
by fungi is often considered one of the pathogenic factors (Dickison, 2000; Prusky et al., 2004) which leads to tissue damage and cell death in plants (Magro, Marciano and di Lenna, 1984; Hadas, Goldberg, Pines and Prusky, 2007). Finally, micromycetes C. cladosporioides and Ph. herbarum, which are common for the Gnetum phylloplane, are known as plant parasites (Pidoplichko, 1977, 1978).

In cork warts, cell destruction occurs; these cells do not contain suberin in their walls and are not covered with cuticle. Destroyed cells are separated from living tissue of the leaf by layers of tightly packed cells with suberized walls. There is no single piece of evidence about penetration of micromycetes through this barrier inside the leaf. Layers of tightly packed cells could be interpreted as "wound periderm".

It is traditionally thought that during the year there is both a period of increasing biodiversity of micromycetes on the leaves of seed plants and a period of its significant decreasing (Blakeman, 1993; Bakkar et al., 2002; Ajay, Aparajita and Das, 2013; Borogohain, Das and Chutia, 2014). Such seasonal changes occur in the phylloplane of the lower epidermis in Gnetum.

The number of micromycetes on the surface of this tissue is extremely reduced in winter and, on the contrary, increases in spring. Seasonal changes in the phylloplane of the upper epidermis occur differently. The total number of species of its micromycetes insignificantly varies throughout the year. At the same time, its composition changes significantly. Disappearing species are replaced by new ones.

The estimation of the Jaccard coefficient for comparison of the lists of micromycetes species that are found on the leaves of the studied plants in spring, autumn and winter has shown that changes in the species composition of mycobiota in G.gnemon and G. montanum phylloplanes in the course of the year occur in a similar way.

The obtained results determine possible directions for further research. Among them, the evaluation of factors that determine the differences between the phylloplanes of the upper and lower epidermis of Gnetum leaves; the identification of climatic preferences of different micromycetes that could successively replace each other in the phylloplane annual seasons; comparison of the phylloplane of unevenly aged leaves; conducting comparative histological and cytological studies of periderm in stems with tissue underlying the cork warts of gnetum leaves.

The structural organization and seasonal changes in the phylloplane, as well as the influence of its micromycetes on leaf cells, differ on the upper and lower surfaces of Gnetum leaves. Cells of cork warts destroyed by micromycetes are isolated from living tissues of leaf by layers of densely arranged cells with suberized walls.
The study showed that the phylloplanes of the upper and lower leaf epidermis of seed plants may differ fundamentally from each other. It also detected the penetration of micromycetes into the damaged epidermis of cork warts, in which they remain isolated from living tissues of the leaf by layers of cells that correspond to a "wound periderm". The obtained data could be taken into account when studying mycobiota of the phylloplane, evaluating their effect on plants and taking measures to combat micromycetes that have settled on the surface of plants. Moreover, the obtained data on the seasonal dynamics of phylloplane mycobiota should be considered in fungicidal spraying of plants growing in the greenhouse.

\section{Acknowledgments}

We express our gratitude to Anna V. Tobias and Julia O. Sapach of the Department of Botany, Saint Petersburg State University, for consultation on methodogy and light microscopy tools; Lubov M. Kartseva of the Laboratory of Scanning Electron Microscopy, Komarov Botanical Institute RAS; Galina Ye. Titova and Lubov A. Pushkareva of the Laboratory of Plant Embryology, Komarov Botanical Institute RAS, for advising in hystochemistry; Marina A. Romanova of the Department of Botany, Saint Petersburg State University, for editing the article.

\section{References}

Ajay, K.S., Aparajita, R., and Das, P. 2013. Fungal colonization of phylloplane of Psidium guineense Sw. growing in Suryamaninagar, Tripura, Northeast India. International Journal of Basic and Applied Chemical Sciences 3(1):62-67.

Andrews, J. H., Spear, R. N., and Nordheim, E. V. 2002. Population biology of Aureobasidium pullulans on apple leaf surfaces. Canadian Journal of Microbiology 48(6):500-513. https://doi.org/10.1139/w02-044

Bakkar, G.R., Frampton, C. M., Jaspers, M. V., Stewart, A., and Walter, M. 2002. Assessment of phylloplane microorganism populations in Canterbury apple orchards. New Zealand Plant Protection 55:129-134. https://doi. org/10.30843/nzpp.2002.55.3941

Barinova, K. V., Vlasov, D. Yu., and Shchiparev, S. M. 2010. Organic acids of micromycetes-biodestructors: Ecological significance, metabolism, dependence on environmental factors. 80 pp. LAP Lambert Academic Publishing GmbH \& Co., Saint Petersburg, Russia. (In Russian)

Barykina, R.P., Veselova, T.D., Devyatov, A. G., Dzhalilova, K. H., lyina, I. G. M., and Churbatova, N. V. 2000. Basis of Microtechnical Research in Botany. 127 pp. MSU, Moscow. (In Russian)

Blakeman, J.P. 1993. Pathogens in the foliar environment. Plant Pathology 42:479-493. https://doi. org/10.1111/j.1365-3059.1993.tb01528.x

Borogohain, A., Das, R., and Chutia, M. 2014. Fungal diversity in phylloplane of castor plant (Ricinus communis L.): the primary food plant of Eri Silkworm. Scholarly Journal of Agricultural Science 4(2):82-86.

Collado, J. G., Platas, I., and Gonzaloz Pelaez, F. 1999. Geographical and seasonal influences on the distribution of fungal endophytes in Quercus ilex. New Phytologist 144:525-532. https://doi.org/10.1046/j.14698137.1999.00533.x

Dickison, W. C. 2000. Integrative Plant Anatomy. 533 pp. San Diego, Academic Press, USA. 
Ellis, M. B. 1971. Dematiaceous Hyphomycetes. 608 pp. CMI, Kew. 1st Edn., Commonwealth Mycological Institute, Kew, Surrey, UK.

Ellis, M. B. 1976. More Dematiaceous Hyphomycetes. 507 p. Commonwealth Mycological Inc., England, USA.

El-Said, A. H. M. 2001. Phyllosphere and phylloplane fungi of banana cultivated in Upper Egypt and their cellulolytic ability. Mycobiology 29(4):210-217. https://doi.org/10.10 80/12298093.2001.12015790

Farooqui, P. 1982. Cork-warts in Eucalyptus species. Proceedings Indian Academy of Sciences 91(4):289-295. https:// doi.org/10.1007/BF03053354

Gonsalez, V. and Tello, M. L. 2010. The endophytic mycota associated with Vitis vinifera in central Spain. Fungal Diversity 47(1):29-42. https://doi.org/10.1007/s13225-010-0073-x

Guimarães, A.R., Andreata, R. H.P., and Costa, C. G. 2011. Stem and leaf morphoanatomy of two Atlantic Forest species of Smilax Linnaeus. Revista De Biologia Neotropical 8(1):1-14. https://doi.org/10.5216/rbn.v8i1.13680

Hadas, Y., Goldberg, I., Pines, O., and Prusky, D. 2007. Involvement of gluconic acid and glucose oxidase in the pathogenicity of Penicillium expansum in apples. Phytopathology 97(3):384-390. https://doi.org/10.1094/PHYTO-97-3-0384

de Hoog, G. and Guarro, J. 1995. Atlas of Clinical Fungi. 720 pp. Centraalbureau voor Schimmelcultures, Baarn, Netherlands. https://doi.org/10.1111/j.1439-0507.1996. tb00088.x

de Hoog, G. S. and Hermanides-Nijhof, E.J. 1977. Survey of the black yeasts and allied fungi. Studies in Mycology 15:178-221.

Inacio, J., Pereira, P., de Carvalho, M., Fonseca, A., Amaral-Collaco, M. T., and Spenser-Martins, I. 2002. Estimation and diversity of phylloplane mycobiota on selected plants in a Mediterranean-type ecosystem in Portugal. Microbial Ecology 44(4):344-353. https://doi.org/10.1007/s00248002-2022-Z

Irga, P. J., Burchett, M. D., O'Reilly, G., and Torpy, F. R. 2006. Assessing the contribution of fallen autumn leaves to airborne fungi in an urban environment. Urban Ecosystems 19(2):885-898. https://doi.org/10.1007/s11252-015-0514-0

Kuthubutheen, A.J. 1984. Leaf surface fungi associated with Avicennia alba and Rhizophora mucornata in Malaysia. In: Proceedings of the Asian symposium on mangrove environment - research and management, 25-29 August 1980. 133-171 pp.

Lee, O. H. K. and Hyde, K. D. 2002. Phylloplane fungi in Hong Kong mangroves: evaluation of study methods. Mycologia 94(4):596-606. https://doi.org/10.2307/3761711
Levetin, E. and Dorsey, K. 2006. Contribution of leaf surface fungi to the air spora. Aerobiologia 22(1):3-12. https:// doi.org/10.1007/s10453-005-9012-9

Levetin, E. 2002. Bioaerosols in agricultural and outdoor settings, in G. Bitton (eds). In: Encyclopedia of Environmental Microbiology. 404-416 pp. NY, USA. https://doi. org/10.1002/0471263397.env184

Luguskas, A. Yu., Mikulskeke, A.l., and Shlyaungene, D. Yu. 1987. Catalogue of micromycetes-biodestructors of materials. 340 pp. Moscow, Nauka. (In Russian)

Magro, P., Marciano, P., and di Lenna, P. 1984. Oxalic acid production and its role in pathogenesis of Sclerotinia sclerotiorum. FEMS Microbiology Letters 24(1):9-12. https://doi. org/10.1111/j.1574-6968.1984.tb01234.x

Pidoplichko, N. M. 1977. Parasite-fungi of cultivated Plants. Vol. 2. 300 pp. Naukova Dumka, Kiev. (In Russian)

Pidoplichko, N. M. 1978. Parasite-fungi of cultivated Plants. Vol. 3. 323 pp. Naukova Dumka, Kiev. (In Russian)

Prabakaran, M., Merinal S., and Panneerselvam, A. 2011. Investigation of phylloplane mycoflora from some medicinal plants. European Journal of Experimental Biology 1(2):219-225.

Prusky, D., McEvoy, J. L., Saftner, R., Conway, W. S., and Jones, R. 2004. Relationship between host acidification and virulence of Penicillium spp. on apple and citrus fruit. Phytopathology 94:44-51. https://doi.org/10.1094/ PHYTO. 2004.94.1.44

Rodolfi, M., Legler, S. E., and Picco, A. M. 2006. Endofiti fungini in Vitis vinifera in Oltrepò Pavese, Northern Italy. Micologia Italiana 35:25-31.

Satton D. A., Fotergill, A., and Rinaldi, M. 2001. Identification guide of pathogenic and facultative pathogenic fungi. 468 pp. Mir Publisher, Moscow, Russia. (In Russian)

Schmidt, V. M. 1984. Mathematical methods in botany. 288 pp. Izdatelstvo Leningradskogo universiteta, Leningrad. (In Russian)

Thakur, S. and Harsh, N.S. K. 2014. Phylloplane fungi as biocontrol agent against Alternaria leaf spot disease of (Akarkara) Spilanthes oleracea. Bioscience Discovery 5(2):139-144.

Vaz, P. P., Souza, P. R., Alves, F. M., and Arruda, R. C. O. 2018. Cork-warts on leaves of Lauraceae: confirming a suspicion. Plant Systematics and Evolution 304(5):723-729. https://doi.org/10.1007/s00606-018-1500-9

Won, H. and Renner, S.S. 2006. Dating dispersal and radiation in the gymnosperm Gnetum (Gnetales) - clock calibration when outgroup relationships are uncertain. Systematic Biology 554(4):610-622. https://doi. org/10.1080/10635150600812619 